\title{
The Comparison of Bond Strength between Geopolymer Concrete and OPC Concrete for Plain Reinforcing Bars
}

\author{
Nuroji $^{1^{*}}$, Daniel Herdian Primadyas ${ }^{2}$, Ilham Nurhuda ${ }^{1}$, and Muslikh ${ }^{3}$ \\ ${ }^{1}$ Dept. Of Civil Engineering, Diponegoro University, Indonesia \\ ${ }^{2}$ Master Program in Civil Engineering, Diponegoro University, Indonesia \\ ${ }^{3}$ Dept. Of Civil Engineering, Gajah Mada University, Indonesia
}

\begin{abstract}
This paper describes the research on bond behavior of plain reinforcing bars in geopolymer and normal concrete. The geopolymer concrete in this research was made of class F fly ash taken from Tanjung Jati Electric Steam Power Plant (PLTU) with Sodium Hydroxide $(\mathrm{NaOH})$ and Sodium Silicate $\left(\mathrm{Na}_{2} \mathrm{SiO}_{3}\right)$ as alkaline activator, added in the mixture. The effect of bar size was studied by varying the bar diameter in range 10 $\mathrm{mm}$ to $19 \mathrm{~mm}$. Each bar was casted in the center of concrete blocks made of geopolymer as well as normal concrete. Pull-out tests were carried out to the specimens that have reached 28 days of age. The test results show that the bond behavior of geopolymer concrete differs substantially from normal concrete, where geopolymer concrete has a higher bond strength when compared to normal concrete with identical concrete strengths.
\end{abstract}

\section{Introduction}

Current data shows that Portland cement concrete making material produces about seven percent of carbon dioxide $\left(\mathrm{CO}_{2}\right)$ [1]. The concentration of $\mathrm{CO}_{2}$ in the atmosphere can dissolve in rain water to form carbonic acid $\left(\mathrm{H}_{2} \mathrm{CO}_{3}\right)$ and falls to earth as acid rain. Hence, to reduce the production of $\mathrm{CO}_{2}$ and to make environment friendly concrete, it is necessary to look for alternate materials to replace part, or all of Portland cement in concrete. In the past decade, research is focused on the study on geopolymer concrete to develop a more environmentally friendly concrete material. Geopolymer concrete is a type of aluminasilicate product and shows good bonding properties. In a fly ash-based geopolymer binder, fly ash reacts with the alkaline solution to create an alumina-silicate binder; no cement is used [2]. Numerous research showed that geopolymer can act as a binding agent in concrete $[3,4]$. Fly ash is one of the materials which is used to produce geopolymer concrete [5]. In the making process of geopolymer concrete, water and binding chemicals such as sodium hydroxide $(\mathrm{NaOH})$ and sodium silicate $\left(\mathrm{Na}_{2} \mathrm{SiO}_{3}\right)$ are required.

As a construction material, the use of concrete is often composed with steel reinforcement, where the reinforcing bar in concrete is to resist tensile stress that cannot be carried by concrete. However, to establish the compatibility action to enable force transfer from the concrete to reinforcing bars or vice versa, a good bond between the steel bars and

*Corresponding author : nuroji.undip@gmail.com 
the concrete becomes mandatory. The bond between reinforcing bars and concrete has been acknowledged as a key to the proper performance of reinforced concrete structures [6].

Previous studies accessed the pull-out test to investigate the behavior of bond between reinforcing bar and geopolymer concrete with a variation in concrete compressive strength and for a range of deformed bar diameters [2]. Alternately, the study of Sarker [7] investigating the bond strength of geopolymer versus conventional concrete reported that the performance of pull-out tests on reinforced geopolymer concrete yielded in a conclusion that a higher bond strength for geopolymer concrete exist when compared to OPC concrete.

The research conducted by Kim and Park (2015) studied the bond using the pull-out tests to investigate the behavior of embedded reinforcements in geopolymer concrete for various compressive strengths and a variation in deformed reinforcement diameter [2]. This paper will elucidate the research result on the bond strength of plain reinforcing bars embedded in geopolymer concrete, compared and OPC.

\section{EXPERIMENTAL STUDIES}

\subsection{Materials}

This research employed fly ash from PLTU Tanjung Jati Jepara as a binder. The type of fly ash depends on the amount of silicon dioxide $\left(\mathrm{SiO}_{2}\right)$, aluminium oxide $\left(\mathrm{Al}_{2} \mathrm{O}_{3}\right)$, and ferrite oxide $\left(\mathrm{Fe}_{2} \mathrm{O}_{3}\right)$. The chemical composition of the fly ash used in this study is as shown in Table 1. It shows that the amount of $\mathrm{SiO}_{2}, \mathrm{Al}_{2} \mathrm{O}_{3}$, and $\mathrm{FeO}$ in the fly ash make up to more than $83 \%$ of the total weight. Therefore, according to ASTM C618 [8], the fly ash can be classified as type $\mathrm{F}$.

Sodium Silicate $\left(\mathrm{Na}_{2} \mathrm{SiO}_{3}\right)$ and Sodium Hydroxide $(\mathrm{NaOH})$ is used as alkaline activator. The ratio between $\mathrm{Na}_{2} \mathrm{SiO}_{3}$ and $\mathrm{NaOH}$ is $2: 1$.

Table 1. Fly Ash Composition (\%)

\begin{tabular}{|c|c|c|c|c|c|c|c|c|c|}
\hline $\mathbf{N a 2 O}$ & $\mathbf{M g O}$ & $\mathbf{A l}_{2} \mathbf{O}_{\mathbf{3}}$ & $\mathbf{S i O}_{2}$ & $\mathbf{S O}_{\mathbf{3}}$ & $\mathbf{K}_{\mathbf{2}} \mathbf{O}$ & $\mathbf{C a O}$ & $\mathbf{T i O}_{2}$ & $\mathbf{F e O}$ & $\mathbf{C u O}$ \\
\hline 1.59 & 2.86 & 25.96 & 46.52 & 1.13 & 2.77 & 5.89 & 1.36 & 11.81 & 1.12 \\
\hline
\end{tabular}

All the aggregates used as concrete-mix in this research were conditioned as saturated surface dry (SSD) before mixing to control the water content of the mix. The composition of the mixture of Geopolymer concrete can be seen in Table 2. The nominal reinforcing bars diameter were $10 \mathrm{~mm}, 12 \mathrm{~mm}, 16 \mathrm{~mm}$, and $19 \mathrm{~mm}$, and three specimens were prepared for every diameter category. The steel bar specimens were tested in the laboratory to determine their effective diameter, yield strength and ultimate strength as shown in Table 3.

Table 2. Mix Proportion

\begin{tabular}{|c|c|}
\hline Material & Mass $\left(\mathbf{k g} / \mathbf{m}^{\mathbf{3}}\right)$ \\
\hline Coarse Aggregate & 1008 \\
\hline Fine Aggregate & 672 \\
\hline Fly Ash (Type F) & 468 \\
\hline
\end{tabular}

\begin{tabular}{|c|c|}
\hline Material & Mass $\left(\mathbf{k g} / \mathbf{m}^{\mathbf{3}}\right)$ \\
\hline $\mathrm{NaOH}(8 \mathrm{M})$ & 84 \\
\hline $\mathrm{Na}_{2} \mathrm{SiO}_{3}$ & 168 \\
\hline
\end{tabular}


Table 3. Properties of Reinforcement Bar

\begin{tabular}{|c|c|c|c|}
\hline Diameter & Effective Diameter $\mathbf{( k g / \mathbf { m } ^ { 3 } )}$ & Yield Strength (MPa) & Ultimate Strength (MPa) \\
\hline 10 & $9.6-$ & 305.09 & 468.27 \\
\hline 12 & 11.80 & 311.44 & 481.09 \\
\hline 16 & 15.23 & 334.77 & 505.72 \\
\hline 19 & 18.75 & 341.03 & 538.879 \\
\hline
\end{tabular}

\subsection{Preparation of Specimens}

In this experiment, pull-out tests were conducted to determine the bond strength behavior. Each bar was embedded in a $150 \times 150 \times 150 \mathrm{~mm}$ concrete cube with a bonded length of $7 \mathrm{D}$, $\mathrm{D}$ being the nominal diameter of the embedded steel bar. To measure the compressive strength of concrete, concrete cylinders $100 \times 200 \mathrm{~mm}$ in size, were casted. To achieve the desired development length of 7D, the contact surface between the concrete and reinforcing bar at the top and bottom ends were separated by using PVC pipe to create a frictionless area between the steel bar and the surrounding concrete (fig. 2). The geopolymer concrete specimens were kept moist for 7 days by using wet gunny-sack covers, and were further stored in room condition until 28 days. All specimens were tested at the age of 28 days.

\subsection{Test Setup}

The test was conducted in the Material and Construction Laboratory, Diponegoro University in Semarang. The incremental load was subjected to the specimen by a tensile force, while the base plate was restrained against movement as shown in figure 2.

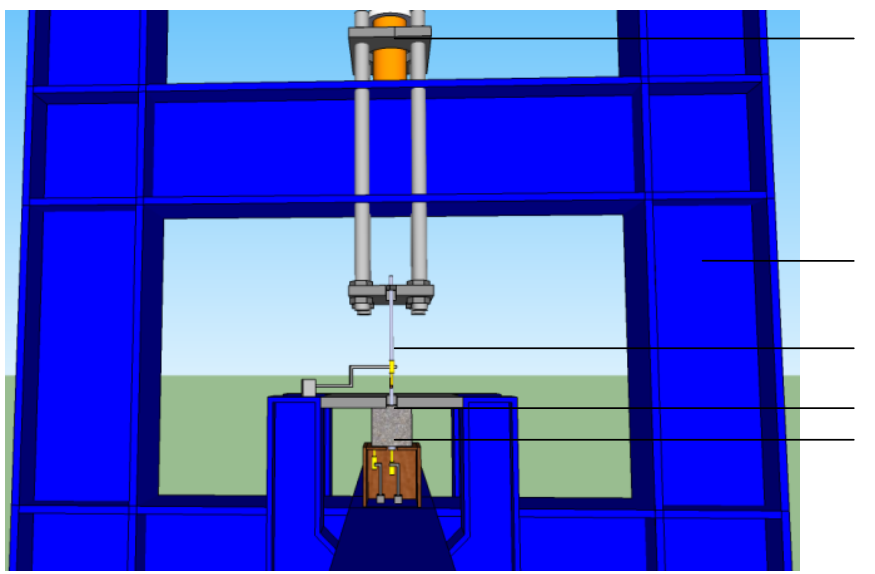

LOAD

CELL

LOADING

FRAME

LVDT

SPECIMEN

LVDT

Fig. 1. Experimental Set Up 


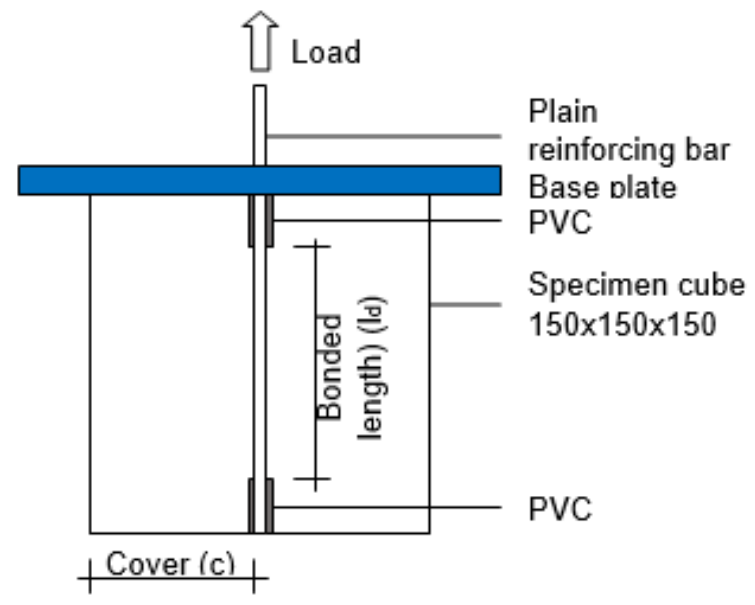

Fig. 2. Pull Out Test Scheme

\section{RESULT AND DISCUSSION}

The bond strength was derived from the maximum load recorded during the test, the average bond strength can then be calculated by dividing the maximum load by the area of contact surface between the reinforcement and the concrete as shown in equation 1 .

$$
\tau=\frac{F}{\pi d_{b} L_{d}}
$$

Where $F, d_{b}$ and $L_{b}$ are force, diameter and bonded length of the bar, respectively. The test results and the calculation of average bond strength are given in Table 4.

Table 4. Bond Test Result

\begin{tabular}{|c|c|c|c|c|c|c|c|}
\hline Specimen & $\begin{array}{c}\boldsymbol{f}_{\mathbf{c}}, \\
(\mathbf{M P a})\end{array}$ & $\begin{array}{c}\text { Bar } \\
\text { diameter } \\
\mathbf{( m m})\end{array}$ & $\mathbf{c} / \mathbf{d}_{\mathbf{b}}$ & $\begin{array}{c}\mathbf{L}_{\mathbf{d}}=\mathbf{7} \\
\mathbf{d}_{\mathbf{b}} \mathbf{( m m )}\end{array}$ & $\begin{array}{c}\text { Bond } \\
\text { Area } \\
\left(\mathbf{m m}^{2}\right)\end{array}$ & $\begin{array}{c}\text { Avg. } \\
\text { Max. } \\
\mathbf{L o a d} \\
\mathbf{( k N )}\end{array}$ & $\begin{array}{c}\text { Avg. Bond } \\
\text { Strength } \\
\mathbf{( M P a )}\end{array}$ \\
\hline GEO-10 & 32.45 & 9.60 & 7.31 & 67.20 & 2026.70 & 18.66 & 9.21 \\
\hline GEO-12 & 32.45 & 11.80 & 5.86 & 82.60 & 3062.05 & 27.11 & 8.86 \\
\hline GEO-16 & 32.45 & 15.23 & 4.42 & 106.61 & 5100.91 & 61.63 & 12.12 \\
\hline GEO-19 & 32.45 & 18.75 & 3.50 & 131.25 & 7731.26 & 77.30 & 10.00 \\
\hline OPC-10 & 30.56 & 9.60 & 7.31 & 67.20 & 2026.70 & 9.02 & 4.45 \\
\hline OPC-12 & 30.56 & 11.80 & 5.86 & 82.60 & 3062.05 & 11.64 & 3.80 \\
\hline OPC-16 & 30.56 & 15.23 & 4.42 & 106.61 & 5100.91 & 30.78 & 6.03 \\
\hline OPC-19 & 30.56 & 18.75 & 3.50 & 131.25 & 7731.26 & 35.86 & 4.64 \\
\hline
\end{tabular}

It can be clearly seen in Table 4 that even though the compressive strength of geopolymer concrete is slightly higher than the OPC concrete, but the average bond strength of geopolymer concrete is twice higher compared to the bond strength of OPC concrete. 


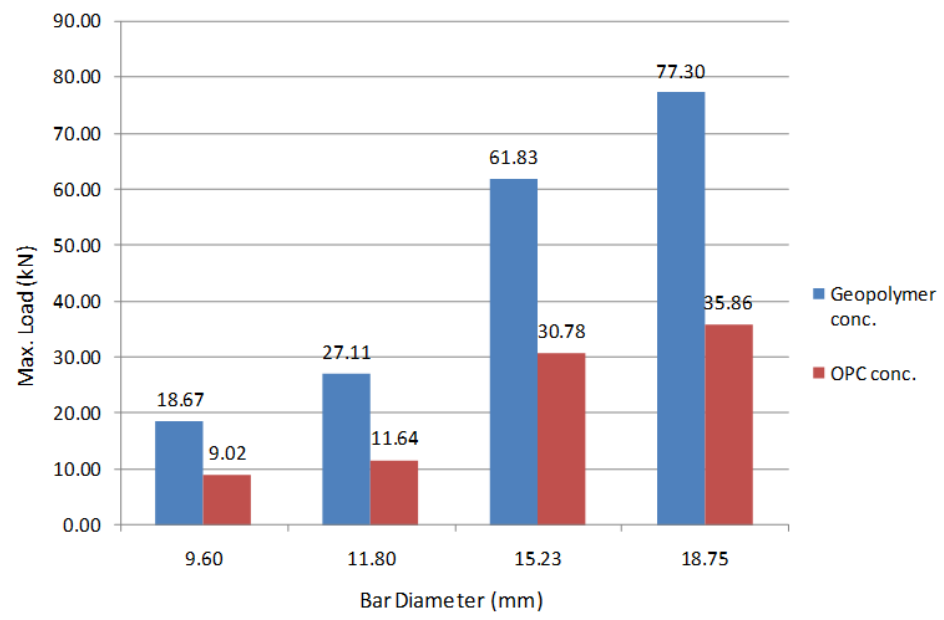

Fig. 3. Maximum load vs bar diameter of geopolymer and OPC concrete

Figure 3 shows the relationship between the maximum load and bar diameter for geopolymer concrete as well as OPC concrete. The relationship shows that the larger the bar diameter, the higher the maximum load to pull of the bars were. This phenomenon was observed for both the geopolymer concrete and OPC concrete. This behavior could be explained due to the fact that the large bar diameter has a larger contact area, when compared to the bars with a smaller diameter, the force transfer through the interface from the steel bar to concrete increases, with the increase of bar diameter. However, the relationship between the maximum load and bar diameter as can be seen in figure 3 approaches a linear pattern, although the interface area is not linear to the bar diameter, where in this research the interface area is determined to be $\pi d_{b}\left(7 d_{b}\right)$. It can be concluded that the maximum load is not only affected by bar diameter, but also influenced by other parameters. The area of interface between steel bar and concrete and passive confinement of concrete play an important role in bond mechanism.

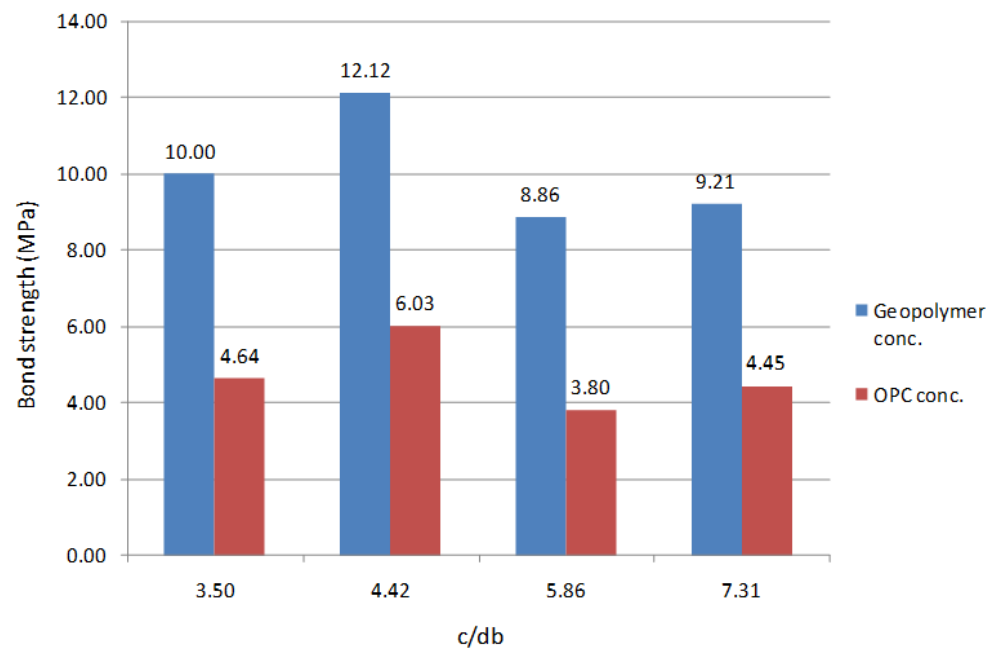

Fig. 4. Bond strength vs cover bar diameter ratio for geopolymer and OPC concrete

Figure 4 shows the relationship between the bond strength and concrete cover-to-bardiameter ratio $\left(\mathrm{c} / \mathrm{d}_{\mathrm{b}}\right)$ for geopolymer concrete and OPC concrete. Where $\mathrm{c}$ being the length 
of the concrete cover, measured from the most out bar diameter to the boundaries of the concrete specimen, and $d_{b}$ being the bar diameter. The bond strength of the geopolymer specimen with a $c / d_{b}$ ratio of 7.31 is slightly higher than that for the specimens with the $c / d_{b}$ ratio of 5.86. Further, the specimen with the $\mathrm{c} / \mathrm{d}_{\mathrm{b}}$ ratio of 4.42 has higher bond strength than that of the specimens with a ratio $\mathrm{c} / \mathrm{d}_{\mathrm{b}}$ equal 3.50 . The phenomenon is almost the same with the OPC concrete specimen. The observation to the specimens show that the failure mechanism of all specimens is characterized by shear failure, no concrete splitting or radial cracks occur for both geopolymer concrete and OPC concrete.

\section{CONCLUSIONS}

The bond strength between plain steel bar for both geopolymer and OPC concrete was investigated in this research. The following conclusions can be drawn form the result:

1. The bond strength of geopolymer concrete is two times higher than the bond strength for OPC concrete, even though the both compressive strengths are relatively being almost identical.

2. The bond strength increase as a function of an increases in concrete cover-todiameter ratio $\left(\mathrm{c} / \mathrm{d}_{\mathrm{b}}\right)$ from 3.50 to 4.42 . But the higher the ratio, the lower the strength. The bond area and thickness of concrete cover are the major contributing factors to this behavior.

3. The increase in bonded length $\left(l_{d}\right)$ from $67.2 \mathrm{~mm}$ to $106.61 \mathrm{~mm}$ enhances the bond strength. However, the increases in bonded length $\left(l_{d}\right)$ from $106.61 \mathrm{~mm}$ to 131.25 $\mathrm{mm}$ yields in a lower bond strength, caused by the absence of passive confining provided by the concrete.

4. Failure mechanism of all specimens are characterized by shear failure, for both the geopolymer and OPC concrete.

\section{References}

1. K. Sathish, S. T. Blessen and C. Alex, "An Experimental Study of the Properties of Glass Fiber Reinforced Geopolymer Concrete," International Journal of Engineering Research and Applications. Vol. 2, no. 6, pp. $722-726$ (2012).

2. Jee-Sang Kim and Jong Ho Park, "An Experimental Bond Properties of Reinforcements Embedded in Geopolymer Concrete." World Academy of Science, Engineering and Technology International Journal of Structural and Construction Engineering Vol:9, No:2, (2015)

3. D. Hardjito, "Properties of Geopolymer Concrete with Fly Ash as it's Source Material," The 21th Biennial Conference of Concrete Institute, (2005).

4. D. Hardjito and B.V. Rangan, "Development and Properties of Low Calcium Fly Ash Based Geopolymer Concrete," Curtin University of Technology, Perth, Australia, (2005).

5. J. Davidovits, Geopolimer: Chemistry and Application. (2008).

6. ACI Committee 408, Bond and Development of Straight Reinforcing Bars in Tension (ACI 408R-03), American Concrete Institute, (2003).

7. P.K. Sarker,Bond Strength of Reinforcing Steel Embedded in Fly Ash based Geopolymer Concrete, Materials and Structures, Vol. 44, Issue 5, pp 1021-1030. (2011).

8. ASTM,Standard Specification for Coal Fly Ash and Raw or Calcined Natural Pozzolan for Use in Concrete, ASTM C618, West Conshohocken, PA, (2012). 